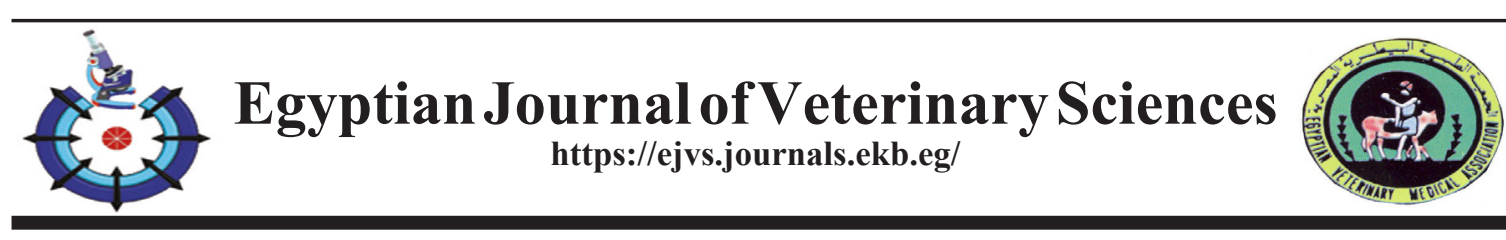

\title{
Isolation and Molecular Identification of Avian Pathogenic Escherichia coli in Broiler Chickens Suffering from Colibacillosis in some Governorates in Egypt
}

\author{
Waleed Abu El-Hammed ${ }^{1 *}$, Hamdy Soufy ${ }^{1}$, A. El-Shemy ${ }^{1}$, Soad M. Nasr ${ }^{1}$ and \\ Mohamed I. Dessouky ${ }^{2}$ \\ ${ }^{1}$ Department of Parasitology and Animal Diseases, National Research Centre, 33 \\ Bohouth Street, Dokki, Giza, 12622, Egypt. \\ ${ }^{2}$ Department of Clinical Pathology, Faculty of Veterinary Medicine, Cairo University, \\ Giza, 12211, Egypt.
}

\begin{abstract}
$\mathbf{T}$ HIS study aimed to evaluate the most predominant strain of avian pathogenic Escherichia coli (APEC) that causes colibacillosis with respiratory manifestation in broiler chickens. Isolation and serotyping identification for the isolates of $E$. coli were performed. Prevalence of APEC differentiated by detection of the 8 virulence-associated genes "astA, iss, irp2, papC $i u c D$, $t s h$, vat, and $c v a / c v i$ " using multiplex PCR technique in the most important isolates of E. coli was also investigated. Antibacterial sensitivity test for antibiotics disc and oregano at different concentrations $(20 \%, 15 \%, 10 \%$, and $5 \%)$, were estimated for the most important isolates of E. coli. A total of 50 broiler farms were located in Gharbia, Giza, Menoufia, Bahaira, and Dakahliah Governorates were examined. Specimens from lung, liver, spleen, and kidney from diseased birds were used for bacteriological examination. Results revealed that E. coli O27 was the most predominant serotype strain (11 out of 35 isolates), followed by the serotypes of O146 (4/35), O Untypable serotypes (4/35), and the (1/35) of each serotype of O8, O20, O44, O78, O114, O125, O142, O152, O153, O158, O164, and O166. One isolate of APEC O27 out of 11 isolates has 6 virulence-related genes "astA, iss, papC, iucD, vat, and cva/cvi". Difloxacin and oregano at a concentration of $20 \%$ have the highest percentage $(100 \%)$ of sensitivity against 11 isolates of $E$. coli $\mathrm{O} 27$ strains. In conclusion, E. coli $\mathrm{O} 27$ was the most predominant serotype infecting farms of broiler chickens. Difloxacin and oregano $20 \%$ could be used for the treatment of APEC O27.
\end{abstract}

Keywords: Molecular, Avian pathogenic E. coli O27, Antibacterial sensitivity test, Broiler chickens.

\section{Introduction}

The poultry sector remains invested in promoting food sustainability in Egypt. Unfortunately, different challenges, including diseases, have resulted in considerable losses in this segment. Escherichia coli (E. coli), is harmless, normal inhabitants of the gastrointestinal tract of animals and human beings [1]. Specific strains of $E$. coli can invade multiple birds' organs, causing peritonitis, perihepatitis, air sacculitis, pericarditis and other extraintestinal infections [2]. Avian colibacillosis is the most common disease leading to significant economic losses to the poultry industry in the world [3].

Collectively, experts have termed extraintestinal conditions as colibacillosis. Avian pathogenic E. coli (APEC) is a causative agent for colibacillosis. The pathogenic capability of $E$. coli is mainly due to multiple virulence

Corresponding author: Waleed Abu El Hammed, E-mail: drwaleedaboelhamed@gmail.com, Tel.: +201117770892

(Received 29/08/2021; accepted 05/09/2021)

DOI. 10.21608/ejvs.2021.93246.1274

C2022 National Information and Documentation Centre (NIDOC) 
factors. The presence of at least six or more of eight virulence-associated genes determines the presence of APEC [4]. The infection relevant by colibacillosis in fowls is pathogenic, might primary or secondary and consequently the symptoms become complicated as a reason of mixed infection. In birds, particularly APEC is the cause strain agents of colibacillosis and this is considered as a serious problem affecting the poultry industries [5]. The categorization of APEC strains is an extraintestinal pathogenic E. coli, this category has a specification characterized by presence of virulence factors that encourage the ability to survive extra-intestinally [6]. Those genes include iron acquisition genes (iucD, iroN), adhesion genes ( $t s h)$, toxin genes ( vat, $h l y F)$, serum resistance genes (iss), housekeeping proteases (ompT), and ColV Operon genes (cvi/cva). The APEC virulent "genes are enteroaggregative toxin (astA), increased serum survival protein (iss), iron-repressible protein (irp2), $\mathrm{P}$ fimbriae (papC), aerobactin (iucD), temperature-sensitive hemagglutinin ( $t s h)$, vacuolating autotransporter toxin (vat), and colicin $\mathrm{V}$ plasmid operon genes (cva/cvi)" [7]. "astA gene encodes for EAST1 (enteroaggregative $E$. coli heat-stable enterotoxin 1), which was first observed in EAEC (enteroaggregative E. coli) strains, that had been recognized as an agent of diarrhea" [8]. Despite the role of EAST1 in pathogenesis still established incompletely, the existence of this toxin was found in high frequency [9-10]. In chickens, iss gene attributes to increased serum survival that has been explained as a significant character of virulent $E$. coli [11]. "iss and the protein which iss encodes were useful targets of colibacillosis" as the reported previous studies [7, 12]. Additionally, in both ColV plasmid and bacterial chromosome, the location of iss gene tends to exist $[6,9,12]$.

Oregano essential oil (Origanum vulgare L.) is an aromatic herbal product that has been used as antibiotic for treatment of $E$. coli due to its phenolic compounds as carvacrol and thymol and their pre-cursors ( $\mathrm{p}$-cymene and $\gamma$-terpinene). Organo essential oil and its components have biological and pharmacological properties that included antimicrobial, antifungal, antiproliferative, antiinflammatory, hepatoprotective, spasmolytic, and vasorelaxant [13-19], microflora balance in the intestine [20] anticoccidial agent [21] immunomodulatory [22], acaricidal activity [23], and antioxidant [24,25] properties. Also, carvacrol-rich oregano oil has high antibiofilm and antivirulence activities against uropathogenic
E. coli [26]. Oregano essential oil is as an antimicrobial and antioxidant additive in food products. Morover it has been used as a growth promoter which has less feed intake and a good feed conversion ratio in broiler chickens [21]. Oregano supplementation in diet improves the growth performance, carcass characteristic and some physiological and immunological parameters of broiler chicks [27]. In addition, oregano modulates microbial species in the intestine and improves their capacity for nutrient absorption, and promotes integrity of the intestinal barrier [28] and itreduces pathogen contamination [29]. So, oregano has a beneficial effect on the function of gut mucosa and digestion.

Therefore, this study aimed to evaluate the most predominant strain of avian pathogenic Escherichia coli that causes colibacillosis with respiratory manifestation in broiler chickens. Isolation and serotyping for $E$. coli isolates were performed. Detection of virulence related genes using multiplex polymerase chain reaction (PCR) technique in the most predominant isolates of $E$. coli was also investigated. Moreover, antibacterial sensitivity test for antibiotics disc and oregano at the concentrations of $20 \%, 15 \%, 10 \%$, and $5 \%$, were estimated for the most important isolates of E. coli.

\section{Materials and Methods}

\section{Broiler Farms Locality}

A total number of 50 broiler farms were examined for isolation and identification of avian pathogenic $E$. coli in chickens suffering from colibacillosis during the period from 2016 to 2017. The age of these birds ranged from the $20^{\text {th }}$ to $37^{\text {th }}$ day old. The capacity of farms was ranging from 1000-27000 birds/farm. These farms are located in 5 Governorates; Gharbia, Giza, Menofia, Bahaira, and Dakahliah (10 Farms/Governorate) in Egypt.

\section{Sampling}

Specimens were collected from lung, liver, spleen, and kidneys of broiler chickens suffering from loss of body weight, mortalities and respiratory manifestations from freshly dead or sacrificed. All samples were given a serial number and detailed information about age, clinical manifestations, postmortem lesions as well as the sample type. This study was conducted regarding to the guidelines of animal experiments and the Institutional Animal Care and Use Committee approval statements protocol, "National Research Centre, Dokki, Giza, Egypt, the protocol approval No.": 1276072021. 


\section{Bacteriological examination}

The isolation methods of $E$. coli from various samples were given in the current study matching the standards of ISO-9308-1:2014 [30]. Specimens from lung, liver, spleen, and kidney were taken under aseptic condition and incubated for $24-48 \mathrm{hrs}$ over night at $37^{\circ} \mathrm{C}$ in nutrient broth then loopfulls from inoculated broth were streaked on MacConkey>s agar (Oxoid, UK) media (selective for Gram-negative Enterobacteriaceae), and Eosin Methylene Blue agar (Oxoid, UK) media (selective for isolation and identification of E. coli). The inoculated media were aerobically incubated at $37{ }^{\circ} \mathrm{C}$ for 24-48 hrs. E. coli colonies have a diameter of 2-3 mm, and light pink colour (Lactose positive) on MacConkey's agar and shiny metallic green colonies on Eosin Methylene Blue agar [31]. Morphological and biochemical identification of the isolates were carried out according to the method of Quinn et al. [32] using the oxidase, catalase, urease, $\mathrm{H}_{2} \mathrm{~S}$ production on TSI, and citrate utilization tests. Other tests including motility test and hemolysis onto blood agar were performed.

\section{Serological detection of E. coli}

Isolation relevant for typing of E. coli was conducted in the Central Laboratory, Veterinary Quality Control- Poultry Production at Animal Health Research Institute, Dokki, Giza, Egypt, according to the method of Ørskov and Ørskov [33].

\section{Antibacterial Assay}

Preparation E. coli $\mathrm{O} 27$ strain suspensions

A suspension of each isolates (11) of E. coli O27 strain was freshly prepared by inoculating fresh stock culture (cultivated for 16 hours) from each isolate into tubes, each containing 7 $\mathrm{ml}$ of Muller Hinton Broth (Oxoid, UK). The inoculated tubes (11) were incubated at $37{ }^{\circ} \mathrm{C}$ for $24 \mathrm{~h}$. Serial dilutions were carried out for each isolate, till dilution matching with 0.5 Mc-Farland scale standard which selected for screening of antimicrobial activities $(\sim$ each inoculum containing about $1 \times 10^{8}$ colony-forming unit $(\mathrm{CFU}) / \mathrm{ml})$.

\section{Antibacterial sensitivity test}

According to the method of Quinn et al., disc diffusion procedure using Muller Hinton agar was illustrated to determine the antibacterial sensitivity of 11 isolates of E. coli O27 [32] and the Clinical and Laboratory Standard Institute (CLSI) recommendations [34, 35].
Routine susceptibility of sixteen antibacterial discs (Oxoid, UK), included difloxacin, gentamycin, cephardin, norfloxacin, amoxicillin, erythromycin, sulphamethoxcin \& trimethoprime, spiramycin, lincomycin, apramycin, cefatrixone, oxytetracycline, ampicillin, cefotaxime, streptomycin, and colistin sulphate. The sensitivity degree was detected by estimation the growth inhibition zone produced by the diffusion of the antibiotic into the surrounding medium followed by the incubation for 24 hours at $37{ }^{\circ} \mathrm{C}$ under aerobic status.

\section{Oregeno solution $20 \%$}

Oregeno solution $20 \%$ (Ropadiar $^{\mathbb{B}}$ ) is derived from Oregano essential oil. It was purchased from ROPA Pharm International Co., Netherlands.

Agar-well diffusion method

The antibacterial activity of different concentrations of oregano (20\% (stock), $15 \%$, $10 \%$, and $5 \%$ ) against 11 isolates of E. coli $\mathrm{O} 27$ was evaluated using agar-well diffusion method according to the procedure of Katircioğlu and Mercan [36]. A $100 \mu 1$ of cell culture suspension (about $1 \times 10^{8} \mathrm{CFU} / \mathrm{ml}$ ) of each isolate was spread onto each agar nutrient plate. For the investigation of the antibacterial activity, $100 \mu \mathrm{l}$ of oregano $20 \%, 15 \%, 10 \%$ and $5 \%$, were poured into the wells of agar plates directly, and were left for $1 \mathrm{~h}$ at $25^{\circ} \mathrm{C}$. The plates were re-incubated at ${ }^{\circ}{ }^{r} \mathrm{C}$ for $r \leqslant \mathrm{~h}$. After incubation, the plates were investigated for antimicrobial activity by estimating the diameters of the inhibition zones for each concentrations of oregano. The tests were run in triplicate for each isolate.

Prevalence of APEC Differentiated using Multiplex PCR

The isolates of E. coli $\mathrm{O} 27$ strain were examined for detection of 8 virulence associated genes "astA, iss, irp2, papC iucD, tsh, vat, and cva/cvi". By using QIAamp DNA Mini kit (Qiagen, Germany, GmbH), bacterial DNA was purified from pure cultures. Primers of specific PCR virulent genes are used and illustrated in Table (1), the primers were supplied via Metabion -Germany. In the $25 \mu \mathrm{l}$ master mix containing $12.5 \mu \mathrm{l}$ of Emerald Amp Max PCR Master Mix -Takara- Japan, $1 \mu \mathrm{l}$ of 20 pmol conc. of each primer, $4.5 \mu \mathrm{l}$ of water and $6 \mu \mathrm{l}$ of template DNA were carried out in each PCR reaction. In Biometra $\mathrm{T} 3$ thermal, the cycling was performed. In this study, eleven of E. coli $\mathrm{O} 27$ strains isolates were subjected to 8 virulent genes to detect virulence of the most isolated strain.

Egypt. J. Vet. Sci. Vol. 53, No. 1 (2022) 
TABLE 1. Oligonucleotide primers sequences (Kwon et al. [4] and Ewers et al. [7])

\begin{tabular}{|c|c|c|c|c|c|}
\hline No. & $\begin{array}{l}\text { Virulent } \\
\text { genes }\end{array}$ & $\begin{array}{l}\text { Primer } \\
\text { sequence }(5,-3 \text { ') }\end{array}$ & $\begin{array}{l}\text { Location within } \\
\text { gene }\end{array}$ & $\begin{array}{l}\text { GenBank } \\
\text { Accession No. }\end{array}$ & $\begin{array}{l}\text { Size } \\
\text { (bp) }\end{array}$ \\
\hline 1 & astA & $\begin{array}{l}\text { TGCCATCAACACAGTATATCC } \\
\text { TCAGGTCGCGAGTGACGGC }\end{array}$ & $\begin{array}{l}797 \sim 817 \\
912 \sim 894\end{array}$ & AF143819 & 116 \\
\hline 2 & Iss & $\begin{array}{l}\text { ATCACATAGGATTCTGCCG } \\
\text { CAGCGGAGTATAGATGCCA }\end{array}$ & $\begin{array}{l}(-) 10 \sim(-) 28 \\
282 \sim 264\end{array}$ & X52665 & 309 \\
\hline 3 & irp2 & $\begin{array}{l}\text { AAGGATTCGCTGTTACCGGAC } \\
\text { AACTCCTGATACAGGTGGC }\end{array}$ & $\begin{array}{l}22 \sim 42 \\
434 \sim 416\end{array}$ & L18881 & 413 \\
\hline 4 & papC & $\begin{array}{l}\text { TGATATCACGCAGTCAGTAGC } \\
\text { CCGGCCATATTCACATAA }\end{array}$ & $\begin{array}{l}1284 \sim 1304 \\
1784 \sim 1767\end{array}$ & Y00529 & 501 \\
\hline 5 & $i u c D$ & $\begin{array}{l}\text { ACAAAAAGTTCTATCGCTTCC } \\
\text { CCTGATCCAGATGATGCTC }\end{array}$ & $\begin{array}{l}239 \sim 259 \\
952 \sim 934\end{array}$ & M18968 & 714 \\
\hline 6 & $T s h$ & $\begin{array}{l}\text { ACTATTCTCTGCAGGAAGTC } \\
\text { CTTCCGATGTTCTGAACGT }\end{array}$ & $\begin{array}{l}132 \sim 151 \\
955 \sim 937\end{array}$ & AF218073 & 824 \\
\hline 7 & Vat & $\begin{array}{l}\text { TCCTGGGACATAATGGTCAG } \\
\text { GTGTCAGAACGGAATTGT }\end{array}$ & $\begin{array}{l}1076 \sim 1095 \\
2056 \sim 2038\end{array}$ & AY151282 & 981 \\
\hline 8 & $\begin{array}{l}c v a \mathrm{~A} / \mathrm{B} \\
c v i c v a \mathrm{C}\end{array}$ & $\begin{array}{l}\text { TGGTAGAATGTGCCAGAGCAAG } \\
\text { GAGCTGTTTGTAGCGAAGCC }\end{array}$ & $\begin{array}{l}10745 \sim 10764 \\
11925 \sim 11904\end{array}$ & AJ223631 & 1,181 \\
\hline
\end{tabular}

\section{Results}

Prevalence of E. coli isolates

The prevalence of $E$. coli isolates among the examined samples revealed that broiler chickens which were located in Gharbia Governorate showed the highest percentage of infection with $E$. coli isolates followed by chickens located in Menoufia, Behira, Giza and Dakahlia Governorates.

The total number of samples collected from broiler chickens were 553, from which 114, 92, 111, 129, and 107 samples were collected from Gharbia, Giza, Menoufia, Bahaira, and Dakahliah Governorates, the positive samples for $E$. coli were 79, 71, 86, 102 and 80, respectively.

\section{Bacterial isolation and identification}

Positive samples of E. coli isolates showed typical pink colonies on MacConkey agar and showed characteristic green metallic sheen on EMB agar. Biochemical characters showed citrate utilization test negative, $\mathrm{H}_{2} \mathrm{~S}$ production in TSI agar negative, indole production positive, urease activity negative, methyle red test positive, VogesProskauer test negative and Lysine decarboxylase positive.
Serological identification of E. coli

Results of the serological identification showed 14 serotypes of $E$. coli as shown in Table (2). The isolated E. coli serotypes are O8, O20, O27, O44, O78, O114, O125, O142, O146, O152, O153, O158, O164, O166, and O Untypable. The isolates of $E$. coli $\mathrm{O} 27$ strain were predominant with percentage of $31.42 \%$ (11 out of 35 ). So, all the eleven E. coli $\mathrm{O} 27$ isolates were subjected to the antibacterial sensitivity test and multiplex PCR technique for detection of genes associated virulence.

\section{Antibacterial sensitivity test}

Antibacterial sensitivity test for 11 isolates of $E$. coli $\mathrm{O} 27$ revealed that difloxacin antibiotic showed sensitive $(100 \%)$ to all the tested isolates. Colistin sulphate was sensitive with a percentage of $63.6 \%$. The most antibiotics used have resistance as shown in Table (3) where a lot of antibiotics showed resistant and intermediate resistance.

Oregano at concentration of $20 \%$ showed the highest percentage $(100 \%)$ of sensitivity against 11 isolates of E. coli $\mathrm{O} 27$ strains. While, oregano $15 \%$ was less sensitive with percentage of $45.5 \%$ (Table 3). 
TABLE 2. Serotypes of Escherichia coli and their detected numbers

\begin{tabular}{cccc}
\hline Serotypes of Escherichia coli & Number & $\begin{array}{c}\text { Percentage } \\
\text { (\%) }\end{array}$ \\
\hline O8 & 1 & 2.86 \\
O20 & 1 & 2.86 \\
O27 & 11 & 31.42 \\
O44 & 1 & 2.86 \\
O78 & 2 & 5.71 \\
O114 & 1 & 2.86 \\
O125 & 2 & 5.71 \\
O142 & 1 & 2.86 \\
O146 & 4 & 11.43 \\
O152 & 1 & 2.86 \\
O153 & 1 & 2.86 \\
O158 & 1 & 5.71 \\
O164 & 2 & 2.86 \\
O166 & 1 & 5.71 \\
Ontypable & 2 & 11.43 \\
\hline Total & 4 & $\mathbf{1 0 0}$ \\
\hline
\end{tabular}

TABLE 3. Antibacterial sensitivity test and MIC of Oregano

\begin{tabular}{|c|c|c|c|c|c|c|c|c|c|c|c|c|}
\hline \multirow[b]{2}{*}{ Antibacterial } & \multicolumn{11}{|c|}{ E. coli $\mathrm{O} 27$ No. } & \multirow{2}{*}{$\begin{array}{c}\% \text { of } \\
\text { sensitivity }\end{array}$} \\
\hline & 1 & 2 & 3 & 4 & 5 & 6 & 7 & 8 & 9 & 10 & 11 & \\
\hline Difloxacin & $\mathrm{S}$ & $\mathrm{S}$ & $\mathrm{S}$ & $\mathrm{S}$ & $\mathrm{S}$ & $\mathrm{S}$ & $\mathrm{S}$ & $\mathrm{S}$ & $\mathrm{S}$ & $\mathrm{S}$ & $\mathrm{S}$ & 100 \\
\hline Gentamycin & $\mathrm{S}$ & $\mathrm{S}$ & $\mathrm{S}$ & I & $\mathrm{R}$ & $\mathrm{R}$ & I & $\mathrm{S}$ & $\mathrm{R}$ & $\mathrm{I}$ & $\mathrm{R}$ & 36.4 \\
\hline Cephradine & $\mathrm{R}$ & $\mathrm{R}$ & $\mathrm{R}$ & $\mathrm{R}$ & $\mathrm{R}$ & I & $\mathrm{S}$ & $\mathrm{R}$ & $\mathrm{R}$ & I & I & 9 \\
\hline Norfloxacin & $\mathrm{S}$ & $\mathrm{R}$ & $\mathrm{R}$ & I & $\mathrm{S}$ & I & $\mathrm{R}$ & $\mathrm{R}$ & S & $\mathrm{I}$ & I & 27.3 \\
\hline Amoxicillin & $\mathrm{R}$ & I & $\mathrm{S}$ & $\mathrm{R}$ & $\mathrm{R}$ & $\mathrm{R}$ & $\mathrm{S}$ & $\mathrm{R}$ & I & $\mathrm{S}$ & I & 27.3 \\
\hline Erythromycin & $\mathrm{S}$ & $\mathrm{R}$ & $\mathrm{R}$ & $\mathrm{S}$ & $\mathrm{R}$ & $\mathrm{R}$ & $\mathrm{R}$ & $\mathrm{R}$ & $\mathrm{S}$ & $\mathrm{R}$ & $\mathrm{S}$ & 36.6 \\
\hline $\begin{array}{l}\text { Sulphamethoxcin } \\
\& \text { trimethoprime }\end{array}$ & $\mathrm{R}$ & I & I & I & $\mathrm{S}$ & I & $\mathrm{S}$ & $\mathrm{R}$ & $\mathrm{R}$ & $\mathrm{S}$ & $\mathrm{S}$ & 36.4 \\
\hline Spiramycin & $\mathrm{S}$ & $\mathrm{R}$ & $\mathrm{R}$ & $\mathrm{S}$ & $\mathrm{R}$ & $\mathrm{S}$ & $\mathrm{R}$ & $\mathrm{R}$ & $\mathrm{S}$ & $\mathrm{R}$ & $\mathrm{R}$ & 36.4 \\
\hline Lincomycin & $\mathrm{R}$ & $\mathrm{R}$ & $\mathrm{R}$ & $\mathrm{R}$ & $\mathrm{R}$ & $\mathrm{R}$ & $\mathrm{R}$ & $\mathrm{R}$ & $\mathrm{R}$ & $\mathrm{R}$ & $\mathrm{R}$ & 0 \\
\hline Apramycin & $\mathrm{S}$ & $\mathrm{R}$ & $\mathrm{R}$ & $\mathrm{S}$ & $\mathrm{R}$ & $\mathrm{S}$ & $\mathrm{R}$ & $\mathrm{R}$ & $\mathrm{S}$ & $\mathrm{R}$ & $\mathrm{R}$ & 36.4 \\
\hline Cefatrixone & $\mathrm{S}$ & $\mathrm{R}$ & $\mathrm{S}$ & I & $\mathrm{S}$ & I & $\mathrm{S}$ & $\mathrm{S}$ & I & I & $\mathrm{S}$ & 54.5 \\
\hline Oxytetracycline & $\mathrm{R}$ & $\mathrm{R}$ & $\mathrm{R}$ & $\mathrm{R}$ & $\mathrm{R}$ & $\mathrm{R}$ & $\mathrm{R}$ & $\mathrm{R}$ & $\mathrm{R}$ & $\mathrm{R}$ & $\mathrm{R}$ & 0 \\
\hline Ampicillin & $\mathrm{R}$ & $\mathrm{R}$ & $\mathrm{R}$ & $\mathrm{R}$ & $\mathrm{R}$ & $\mathrm{R}$ & $\mathrm{R}$ & $\mathrm{R}$ & $\mathrm{R}$ & $\mathrm{R}$ & $\mathrm{R}$ & 0 \\
\hline Cefotaxime & $\mathrm{S}$ & $\mathrm{R}$ & $\mathrm{S}$ & $\mathrm{R}$ & $\mathrm{S}$ & $\mathrm{S}$ & $\mathrm{R}$ & $\mathrm{R}$ & $\mathrm{S}$ & $\mathrm{R}$ & $\mathrm{R}$ & 45.5 \\
\hline Streptomycin & $\mathrm{R}$ & $\mathrm{R}$ & $\mathrm{R}$ & $\mathrm{R}$ & $\mathrm{R}$ & $\mathrm{R}$ & $\mathrm{R}$ & $\mathrm{R}$ & $\mathrm{R}$ & $\mathrm{R}$ & $\mathrm{R}$ & 0 \\
\hline Colistine sulphate & $\mathrm{S}$ & $\mathrm{R}$ & $\mathrm{R}$ & $\mathrm{S}$ & $\mathrm{S}$ & $\mathrm{S}$ & $\mathrm{S}$ & $\mathrm{R}$ & $\mathrm{R}$ & $\mathrm{S}$ & $\mathrm{S}$ & 63.6 \\
\hline Oregano $20 \%$ & $\mathrm{~S}$ & $\mathrm{~S}$ & $\mathrm{~S}$ & $\mathrm{~S}$ & $\mathrm{~S}$ & $\mathrm{~S}$ & $\mathrm{~S}$ & $\mathrm{~S}$ & $\mathrm{~S}$ & $\mathrm{~S}$ & $\mathrm{~S}$ & 100 \\
\hline Oregano 15\% & $\mathrm{S}$ & $\mathrm{S}$ & I & I & $\mathrm{S}$ & I & $\mathrm{S}$ & I & $\mathrm{S}$ & $\mathrm{S}$ & I & 45.5 \\
\hline Oregano $10 \%$ & $\mathrm{R}$ & $\mathrm{R}$ & $\mathrm{R}$ & $\mathrm{R}$ & $\mathrm{R}$ & $\mathrm{R}$ & $\mathrm{R}$ & $\mathrm{R}$ & $\mathrm{R}$ & $\mathrm{R}$ & $\mathrm{R}$ & 0 \\
\hline Oregano $5 \%$ & $\mathrm{R}$ & $\mathrm{R}$ & $\mathrm{R}$ & $\mathrm{R}$ & $\mathrm{R}$ & $\mathrm{R}$ & $\mathrm{R}$ & $\mathrm{R}$ & $\mathrm{R}$ & $\mathrm{R}$ & $\mathrm{R}$ & 0 \\
\hline
\end{tabular}


Detection of Virulence-associated genes

Results revealed that one isolate APEC O27 has 6 virulence related genes "ast A, iss, pap $C$, $i u c D$, vat and $c v a / c v i$ " from eleven isolates of $E$. coli $\mathrm{O} 27$ serotype.

In this illustrated Fig.1, there were three isolates of E. coli O27 that have virulenceassociated genes; Two isolates have 3 virulenceassociated genes -non APEC O27- (Fig. 1: lanes $1 \& 2$ ) and one isolate only has 6 virulenceassociated genes -APEC O27- (Fig. 1: lane 3). Control negative has no virulence-associated genes (Fig. 1: -ve).

\section{Discussion}

This study was conducted to evaluate the most predominant strain of APEC causing colibacillosis with respiratory manifestation in broiler chickens in farms located in the Governorates of Giza, Menofia, Bahaira, Dakahliah and Gharbia in Egypt. Isolation and molecular identification of $E$. coli were performed by bacteriological, biochemical and serological diagnosis. Antibacterial sensitivity test of different types of antibiotics discs, and oregano at different concentrations $(20 \%, 15 \%, 10 \%$, and $5 \%)$ against APEC O27 were also investigated.

In this study, isolates of E. coli $\mathrm{O} 27$ strains showed high level of resistance against amoxicillin, ampicillin, oxytetracycline, trimetoprim-sulfamethoxazole, lincomycin, streptomycin, norfloxacin, cephradine, and spiramycin but high sensitive to difloxacin. Similar result weas recorded by Messaï et al. [37] who studied the antimicrobial resistance of APEC strains responsible for colibacillosis in broiler breeding farms in eastern Algeria and Sarker et al. [38] reported resistance to ampicillin and tetracycline among multi drug resistance (MDR) E. coli isolated from broiler chickens. Moawad et al. [39] observed high resistant E. coli isolates from raw chicken meat with the different antibiotics (ampicillin (71.4\%), tetracycline (80.9\%), streptomycin (61.9\%), trimethoprim/ sulphamethoxazole $(61.9 \%)$, and cefotaxime $33.3 \%$ ). Several international studies have investigated the phenotypic resistance profile of E. coli isolates from chicken, such as those conducted in Saudi Arabia [40], Algeria [41], Canada [42], and the Netherlands [43].

In the present work, oregano $20 \%$ showed the highest percentage $(100 \%)$ of antimicrobial activity against 11 isolates of $E$. coli $\mathrm{O} 27$ strain due Egypt. J. Vet. Sci. Vol. 53, No. 1 (2022) to presence of phenolic compounds as carvacrol and thymol and their pre-cursors (p-cymene and $\gamma$-terpinene) which have potential antimicrobial agents against several types of both Gram negative and Gram positive bacteria [44, 45]. The most important bacteriostatic component in oregano oil is carvcacrol. The mechanism of action of carvacrol on cell membrane of the food-borne pathogen Bacillus cereus reported by Ultee et al. [46] revealed that carvacrol interacts with the cell membranes of bacteria by alteration its permeability for cations (as hydrogen ion $\left(\mathrm{H}^{+}\right)$and potassium ion $\left(\mathrm{K}^{+}\right)$). The removal of ion gradients leads to impairment of essential processes in the cell lead finally to cell death. Farag et al. [47] and Smink [48] recorded that the high antioxidant activity of thymol (a bioactive component presents in essential oil of oregano), is due to the presence of phenolic $\mathrm{OH}$ groups which act as hydrogen donors to the peroxy radicals that produced during the first step in lipid oxidation, thus, retarding the hydroxy peroxide formation. Antioxidant and antibacterial activity of oregano essential oil [49, $50]$ is due to free radical scavenging activity, total reducing capacity and prevent autoxidation of polyunsaturated fatty acid esters [51]. Moreover, organo essential oil act as anti-inflammatory by inhibiting the inflammatory biomarkers levels; monocyte chemoattractan protein-1 (MCP-1), the vascular cell adhesion molecule-1 (VCAM1) and the intracellular cell adhesion molecule-1 (ICAM-1) (MCP-1, VCAM-1 and ICAM-1), and decrease synthesis of cytokines; tumor necrosis factor- alpha (TNF- $\alpha$ ), interleukin (IL)-6, IL-1 $\beta$, and IL-6 and Increased synthesis of cytokine IL-10 [22]. So, oregano has antiinflammatory and antimicrobial effects [52], by modulating the cytokine levels and immunityrelated transcription factors [28]. Also, carvacrol reduces the severity of inflammation by the production of mediators of inflammation and protein concentration as well as the gene expression modulation of interleukins [53]. Burt and Reinders [54] recorded that $625 \mu$ l of organo essential oil/L have antibacterial activity which causes irreversible damage within 1 min against E. coli O157:H7. Da Costa et al. [55] reported that the minimum inhibitory concentration (MIC) of Origanum vulgare essential oil against E. coli was inhibited (100\%) at the concentration of $0.125 \%$. While, Pei et al. [56] found that thymol/carvacrol components have antibacterial activity against $E$. coli at $400 \mathrm{mg} / 1$. 


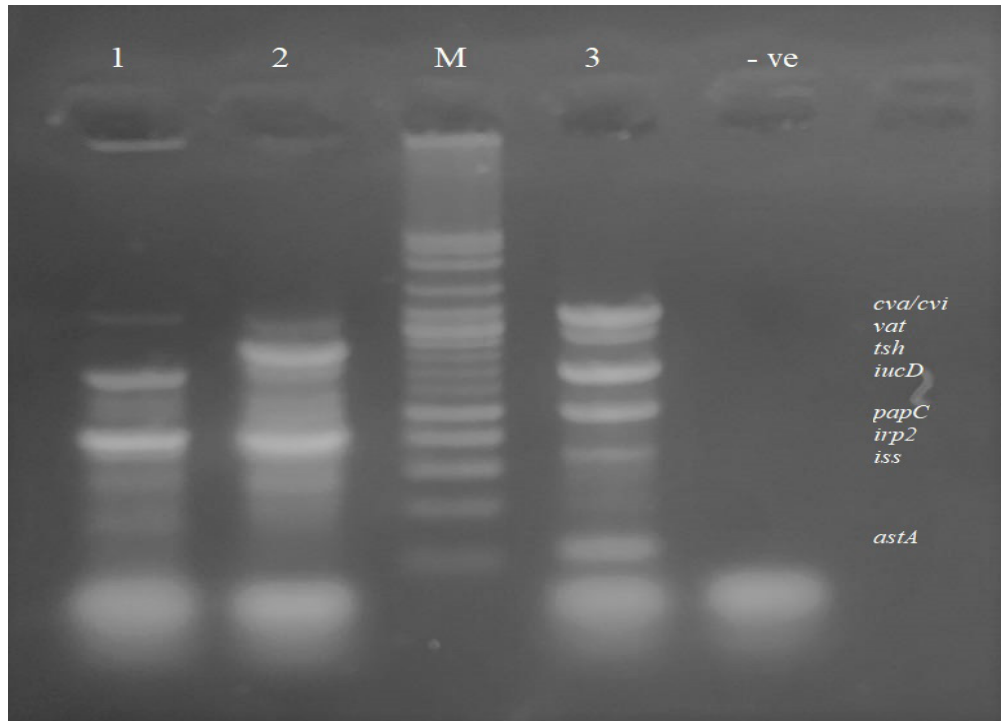

Fig. 1. Amplicon patterns of virulence-associated genes of E. coli strain differentiated by multiplex PCR. M: 100 bp ladder, Lane 1: had 3 virulence-associated genes (irp2, iucD and cva/cvi), Lane 2: had 3 virulenceassociated genes (irp2, tsh and cva/cvi), Lane 3: E.coli-O27 had 6 virulence related genes "astA, iss, papC, iucD, vat and cva/cvi" and Lane - ve: control negative.

The virulence related genes rates and the combinational abilities of APEC within targeted 8 virulence associated genes were studied [4]. In the present study, one isolate APEC O27 has 6 virulence related genes "ast A, iss, papC, iucD, vat and cva/cvi" from eleven isolates of E. coli $\mathrm{O} 27$ serotype. Subedi et al. [1] found similar APECassociated virulence genes in broiler chickens in Nepal. In previous study, Kwon et al. [4] found 4 virulence genes (iss, vat, iucD and cvi/cva) among 18 avian E. coli strains.

In this study, one isolate of APEC O27 has the most virulent genes of pathogenicity and could cause severe losses in the broiler farms.

\section{Conclusion}

E. coli $\mathrm{O} 27$ strains were the most predominant serotype infected chickens in broiler farms. APEC $\mathrm{O} 27$ possessed the six virulent associated genes of pathogenicity and could cause severe losses in the broiler farms. Difloxacin and oregano $20 \%$ could be used for the treatment of APEC O27. Further investigations should be performed experimentally to study the pathogenesis of local isolate APEC O27 strain in broiler chickens and trails for its treatment.

\section{Acknowledgement}

The authors are grateful to Dr. Haytham M. Hawash, Researcher of Microbiology \&Food Safety, in Reference Laboratory for Veterinary Quality Control, Animal Health Institute for his help in typing of $E$. coli isolates, and Dr. Hend H.A.M. Abdullah Researcher of Animal Diseases in Department of Parasitology and Animal Diseases, National Research Centre, for her help in multiplex PCR.

Conflict of Interest

None.

Funding Statements

None.

\section{$\underline{\text { References }}$}

1. Subedi, M., Luitel, H., Devkota, B., Bhattarai, R.K., Phuyal, S., Panthi, P., Shrestha, A., and Chaudhary, D.K. Antibiotic resistance pattern and virulence genes content in avian pathogenic Escherichia coli (APEC) from broiler chickens in Chitwan, Nepal. BMC Vet. Res., 14, p113 (2018). https://doi. org/10.1186/s12917-018-1442-z

2. Vaish, R., Pradeep, M., Setty, C. and Kandi, V. Evaluation of virulence factors and antibiotic sensitivity pattern of Escherichia coli isolated from extraintestinal infections. Cureus, 8(5), e604 (2016). https://doi.org/10.7759/cureus.604

3. Paixao, A.C., Ferreira, A.C., Fontes, M., Themudo, P., Albuquerque, T., Soares, M.C., Fevereiro, M., Martins, L. and Correa de Sa, M.I. Detection of virulence-associated genes in pathogenic and commensal avian Escherichia coli isolates, Poult. Sci., 95(7), 1646-1652 (2016). https://doi. org/10.3382/ps/pew087

Egypt. J. Vet. Sci. Vol. 53, No. 1 (2022) 
4. Kwon, S.-G., Cha, S.-Y., Choi, E.-J., Kim, B., Song, H.-J. and Jang, H.-K. Epidemiological prevalence of avian pathogenic Escherichia coli differentiated by multiplex PCR from commercial chickens and hatchery in Korea. J. Bacteriol. Virol., 38(4), 179-188 (2008). https://doi.org/10.4167/ jbv.2008.38.4.179

5. Barnes, H.J., Nolan, L.K. and Vaillancourt, J.P. Colibacillosis. In Diseases of Poultry. 12th ed, Saif YM, Fadly AM, Glisson JR, McDougald LR, Nolan LK, Swayne DE (Eds.), Blackwell Pub. Professional, Ames, Iowa, pp. 691-732. (2008).

6. Johnson, T.J., Siek, K.E., Johnson, S.J. and Nolan, L.K. DNA sequence of a ColV plasmid and prevalence of selected plasmid-encoded virulence genes among avian Escherichia coli strains. J. Bacteriol.,188(2),745-758 (2006). https://doi. org/10.1128/JB.188.2.745-758.2006

7. Ewers, C., Janssen, T., Kießling, S., Philipp, H.C. and Wieler, L.H. Rapid detection of virulenceassociated genes in avian pathogenic Escherichia coli by multiplex polymerase chain reaction. Avian Dis., 49(2), 269-273 (2005) https://doi. org/10.1637/7293-102604R

8. Ménard, L.-P. and Dubreuil, J.D. Enteroaggregative Escherichia coli heat-stable enterotoxin 1 (EAST1): a new toxin with an old twist. Crit. Rev. Microbiol., 28(1), 43-60(2002). https://doi.org/10.1080/1040840291046687

9. Veilleux, S. and Dubreuil, J.D. Presence of Escherichia coli carrying the EAST1 toxin gene in farm animals. Vet. Res., 37(1), 3-13, (2006). https:// doi.org/10.1051/vetres:2005045

10. Yamamoto, T. and Nakazawa, M. Detection and sequences of the enteroaggregative Escherichia coli heat-stable enterotoxin 1 gene in enterotoxigenic E. coli strains isolated from piglets and calves with diarrhea. J. Clin. Microbiol., 35(1), 223-227 (1997). https://doi.org/10.1128/jcm.35.1.223-227.1997

11. Ellis, M.G., Arp, L.H. and Lamont, S.J. Serum resistance and virulence of Escherichia coli isolated from turkeys. Am. J. Vet. Res., 49(12), 2034-2037 (1988).

12. Pfaff-McDonough, S.J., Horne, S.M., Giddings, C.W., Ebert, J.O., Doetkott, C., Smith, M.H. and Nolan, L.K. Complement resistance-related traits among Escherichia coli isolates from apparently healthy birds and birds with colibacillosis. Avian Dis., 44(1), 23-33 (2000).
13. H. Sakkas, C. Papadopoulou, Antimicrobial activity of Basil, oregano, and thyme essential oils, J. Microbiol. Biotechnol., 27, 429-438 (2017). https://doi.org/10.4014/jmb.1608.08024

14. Thompson, D.P. Fungitoxic activity of essential oil components on food storage fungi, Mycologia., 81, 151-153 (1989). https://doi.org/10.1080/00275514. 1989.12025637

15. Leyva-López, N., Gutiérrez-Grijalva, E.P., Vazquez-Olivo, G. and Heredia, J.B. Essential oils of oregano: Biological activity beyond their antimicrobial properties, Molecules. 22, 989p (2017). https://doi.org/10.3390/molecules22060989

16. Suntres, Z. E., Coccimiglio, J. and Alipour, M. The bioactivity and toxicological actions of carvacrol. Crit. Rev. Food Sci. Nutr., 55(3), 304318(2015). http://dx.doi.org/10.1080/10408398. 2011.653458

17. Terenina, M.B., Misharina, T.A., Krikunova, N.I., Alinkina, E.S., Fatkulina, L.D. and Vorob'yova, A.K. Oregano essential oil as an inhibitor of higher fatty acid oxidation. Appl. Biochem. Microbiol., 47, 445-449 (2011). doi: 10.1134/ S0003683811040181.

18. Marrelli, M., Conforti, F., Formisano, C., Rigano, D., Arnold, N.A., Menichini, F. and Senatore, F. Composition, antibacterial, antioxidant and antiproliferative activities of essential oils from three Origanum species growing wild in Lebanon and Greece. Nat. Prod. Res., 30, 735-739 (2016). doi: 10.1080/14786419.2015.1040993 .

19. Sarikurkcu, C., Zengin, G., Oskay, M., Uysal, S., Ceylan, R. and Aktumsek, A. Composition, antioxidant, antimicrobial and enzyme inhibition activities of two Origanum vulgare subspecies (subsp. vulgare and subsp. hirtum) essential oils. Ind. Crop. Prod., 70, 178-184. doi: 10.1016/j.indcrop.2015.03.030

20. Turcu, R.P., Tabuc, C., Vlaicu, P.A., Panaite, T.D., Buleandra, M. and Saracila, M. Effect of the dietary oregano (Origanum vulgare L.) powder and oil on the balance of the intestinal microflora of broilers reared under heat stress $\left(32^{\circ} \mathrm{C}\right)$. Scientific Papers. Series D. Animal Sci., LXI (1), 77-86 (2018).

21. Alp, M., Midilli, M., Kocabağlı, N., Yılmaz, H., Turan, N., Gargili, A., and Acar, N. The effects of dietary oregano essential oil on live performance, carcass yield, serum immunoglobulin G level, and oocyst count in broilers. J. Appl. Poult. Res., 21, 630-636 (2012). https://doi.org/10.3382/japr.201200551 
22. Han, X. and Parker, T.L. Anti-inflammatory, tissue remodeling, immunomodulatory, and anticancer activities of oregano (Origanum vulgare) essential oil in a human skin disease model. Biochim. Open. 4, 73-77 (2017). doi: 10.1016/j.biopen.2017.02.005.

23. Shang, X., Wang, Y., Zhou, X., Guo, X., Dong, S., Wang, D., Zhang, J., Pan, H., Zhang, Y. and Miao, X. Acaricidal activity of oregano oil and its major component, carvacrol, thymol and p-cymene against Psoroptes cuniculi in vitro and in vivo, Vet. Parasitol., 226, 93-96 (2016). https://doi. org/10.1016/j.vetpar.2016.07.001

24. Ozdemir, N., Ozgen, Y., Kiralan, M., Bayrak, A., Arslan, N. and Ramadan, M.F. Effect of different drying methods on the essential oil yield, composition and antioxidant activity of Origanum vulgare L. and Origanum onites L. J. Food Meas. Charact., 12, 820-825 (2018). https://doi. org/10.1007/s11694-017-9696-x

25. Diniz do Nascimento, L., Moraes, A.A.B., Costa, K.S.D., Pereira Galúcio, J.M., Taube, P.S., Costa, C.M.L., Neves Cruz, J., de Aguiar Andrade, E.H. and Faria, L.J.G., Bioactive natural compounds and antioxidant activity of essential oils from spice plants: New findings and potential applications. Biomolecules. 10, 988, pages 1-35(2020). https:// doi.org/10.3390/biom10070988

26. Lee, J.H., Kim, Y.G. and Lee, J. Carvacrol-rich oregano oil and thymol-rich thyme red oil inhibit biofilm formation and the virulence of uropathogenic Escherichia coli, J. Appl. Microbiol., 123, 14201428 (2017). https://doi.org/10.1111/jam.13602

27. Bahakaim, S.A., Abdel-Halim, H.A.H., Mousa, S.M.M. and Fadl, A. Effect of dietary oregano supplementation on productive, physiological and immunological performance of broiler chicks. Egypt. Poult. Sci., 40(II), 507-524 (2020).

28. Zou, Y., Xiang, Q., Wang, J., Peng, J. and Wei, H. Oregano essential oil improves intestinal morphology and expression of tight junction proteins associated with modulation of selected intestinal bacteria and immune status in a pig model. Biomed. Res. Int., 2016, 5436738 (2016). doi: $10.1155 / 2016 / 5436738$

29. Amrik, B. and Bilkei, G. Influence of farm application of oregano on performances of sows. Can. Vet. J., 45(8), 674-677 (2004).

30. Fricker, C.R., Bullock, S., Murrin, K. and Niemela, S.I: Use of the ISO 9308-1 procedure for the detection of $E$. coli in water utilizing two incubation temperatures and two confirmation procedures and comparison with defined substrate technology. $J$. Water Health, 6(3), 389-397 (2008).

31. Swayne, D.E. Glisson, J.R. Jackwood, M.W. Pearson, J.E. and Reed, W.M. Isolation and identification of avian pathogens. 5th ed., University of Pennsylvania New Bolton Center, Kennett square, PA, (2008).

32. Quinn, P.J., Markey, B.K, Leonard, F.C., Archambault, M., Cullinane, A., Maguire, D. and Carter, M.E.. Clinical Veterinary Microbiology. 2nd ed., Mosby Ltd, UK. (2013)

33. Ørskov, F. and Ørskov, I. Serotyping of Escherichia coli. In: Bergan T. (Ed.) Methods in Microbiology. Vol. I $\leq$ London: Academic Press, pp. 43-112 (1984).

34. CLSI (Clinical and Laboratory Standard Institute). Performance Standards for Antimicrobial Susceptibility Testing- M100-S26. Twenty-six informational supplement. Wayne, Pensylvania, pp 296 (2016).

35. CLSI (Clinical and Laboratory Standard Institute). Performance Standards for Antimicrobial Susceptibility Testing. 29 ${ }^{\text {th }}$ ed., CLSI supplement M100. Wayne, Pensylvania, 320p. (2019).

36. Katircioğlu, H. and Mercan, N. Antimicrobial activity and chemical compositions of Turkish propolis from different regions. Afr. J. Biotechnol., 5(11), 1151-1153 (2006)

37. Messaï, C.R., Aït-Oudhia, K., Khelef, D., Hamdi, T.M., Chenouf, N.S. and Messaï, M.R. Serogroups and antibiotics susceptibility pattern of avian pathogenic Escherichia coli strains responsible for colibacillosis in broiler breeding farms in the east of Algeria. Afr. J. Microbiol. Res., 9(49), 2358-2363 (2015). https://doi.org/10.5897/AJMR2015.7600

38 .Sarker, M.S., Mannan, M.S., Ali, M.Y., Bayzid, M., Ahad, A. and Bupasha, Z.B. Antibiotic resistance of Escherichia coli isolated from broilers sold at live bird markets in Chattogram, Bangladesh. $J$. Adv. Vet. Anim. Res., 6(3), 272-277 (2019). https:// doi.org/10.5455/javar.2019.f344

39. Moawad, A.A., Hotzel, H., Awad, O., Tomaso, H., Neubauer, H., Hafez, H.M. and El-Adawy, H. Occurrence of Salmonella enterica and Escherichia coli in raw chicken and beef meat in northern Egypt and dissemination of their antibiotic resistance markers. Gut. Pathog., 9, 57, pages 1-13(2017). https://doi.org/10.1186/s13099-017-0206-9

Egypt. J. Vet. Sci. Vol. 53, No. 1 (2022) 
40. Altalhi, A.D., Gherbawy, Y.A. and Hassan, S.A. Antibiotic resistance in Escherichia coli isolated from retail raw chicken meat in Taif, Saudi Arabia. Foodborne Pathog. Dis., 7 (3), 281-285 (2010). https://doi.org/10.1089/fpd.2009.0365

41. Laarem, M., Barguigua, A., Nayme, K., Akila, A., Zerouali, K., El Mdaghri, N. and Timinouni, M. Occurrence of plasmid-mediated quinolone resistance and virulence genes in avian Escherichia coli isolates from Algeria. J. Infect. Dev. Ctries., 11(2), 143-151 (2017). https://doi.org/10.3855/jidc. 8643

42. Romero-Barrios, P., Deckert, A., Parmley, E.J. and Leclair, D. Antimicrobial resistance profiles of Escherichia coli and Salmonella isolates in Canadian broiler chickens and their products. Foodborne Pathog. Dis., 17(11), 672-678 (2020). https://doi.org/10.1089/fpd.2019.2776

43. Overdevest, I., Willemsen, I., Rijnsburger, M., Eustace, A., Xu, L., Hawkey, P., Heck, M.,Savelkoul, P., Vandenbroucke-Grauls, C., van der Zwaluw, K., Huijsdens, X. and Kluytmans, J. Extended-spectrum $\beta$-lactamase genes of Escherichia coli in chicken meat and humans, The Netherlands. Emerg. Infect. Dis., 17(7), 1216-1222 (2011). https://doi.org/10.3201/eid1707.110209

44. Dorman, H.J.D. and Deans, S.G. Antimicrobial agents from plants: Antibacterial activity of plant volatile oils. J. Appl. Microbiol., 88(2), 308-316 (2000). https://doi.org/10.1046/j.13652672.2000.00969.x

45. Solomakos, N., Govaris, A., Koidis, P. and Botsoglou, N. The antimicrobial effect of thyme essential oil, nisin, and their combination against Listeria monocytogenes in minced beef during refrigerated storage. Food Microbiol., 25(1),120-127. (2008). https://doi.org/10.1016/j. fm.2007.07.002

46. Ultee, A., Kets, E.P.W. and Smid, E.J. Mechanisms of action of carvacrol on the foodborne pathogen Bacillus cereus. Appl. Environ. Microbiol., 65(10), 4606-4610 (1999).

47. Farag, R.S. Daw , Z.Y. Hewedi , F.M. and El-Baroty G.S.A. Antimicrobial Activity of Some Egyptian Spice Essential Oils. J. Food Prot., 52(9), 665-667 (1989)

48. Smink, W. Oregano oil boost. Pig. Progress, 19(3), 24-25 (2003).
49. Sarikurkcu, C., Zengin, G., Oskay, M., Uysal, S., Ceylan, R. and Aktumsek, A. Composition, antioxidant, antimicrobial and enzyme inhibition activities of two Origanum vulgare subspecies (subsp. vulgare and subsp. hirtum) essential oils. Ind. Crop. Prod., 70, 178-184 (2015). doi: 10.1016/j.indcrop.2015.03.030

50. Gavaric, N., Mozina, S.S., Kladar, N. and Bozin, B. Chemical profile, antioxidant and antibacterial activity of thyme and oregano essential oils, thymol and carvacrol and their possible synergism. $J$. Essent. Oil Bear. Plants, 18, 1013-1021 (2015). doi: 10.1080/0972060X.2014.971069

51. Terenina, M.B., Misharina, T.A., Krikunova, N.I., Alinkina, E.S., Fatkulina, L.D. and Vorob'yova, A.K. Oregano essential oil as an inhibitor of higher fatty acid oxidation. Appl. Biochem. Microbiol., 47, 445-449 (2011). https://doi.org/10.1134/S0003683811040181.

52. Listorti, V., Battistini, R., Ercolini, C., Tramuta, C., Razzuoli, E. and Vencia, W. In vitro susceptibility of multidrug resistant strains of salmonella to essential oils. Nat. Prod. Commun., 15:1934578X19878904 (2020). doi: 10.1177/1934578X19878904

53. Kara, M., Uslu, S., Demirci, F., Temel, H.E. and Baydemir, C. Supplemental carvacrol can reduce the severity of inflammation by influencing the production of mediators of inflammation. Inflammation., 38:1020 1027 (2015). doi: 10.1007/s10753-014-0066-0

54. Burt, S.A. and Reinders, R.D. Antibacterial activity of selected plant essential oils against Escherichia coli O157:H7. Lett. Appl. Microbiol., 36(3), 162-167 (2003). https://doi.org/10.1046/j.1472765X.2003.01285.x

55. Da Costa, A.C., Dos Santos, B.H.C., Filho, L.S. and Lima, E.D.O. Antibacterial activity of the essential oil of Origanum vulgare L. (Lamiaceae) against bacterial multiresistant strains isolated from nosocomial patients. Revista Brasileira De Farmacognosia, 19 (1B), 236-241 (2009). https:// doi.org/10.1590/S0102-695X2009000200010

56. Pei, R.-S., Zhou, F., Ji, B.-P. and Xu, J. Evaluation of combined antibacterial effects of eugenol, cinnamaldehyde, thymol, and carvacrol against $E$. coli with an improved method. J. Food Sci., 74(7), M379-383 (2009). https://doi.org/10.1111/j.17503841.2009.01287.x 


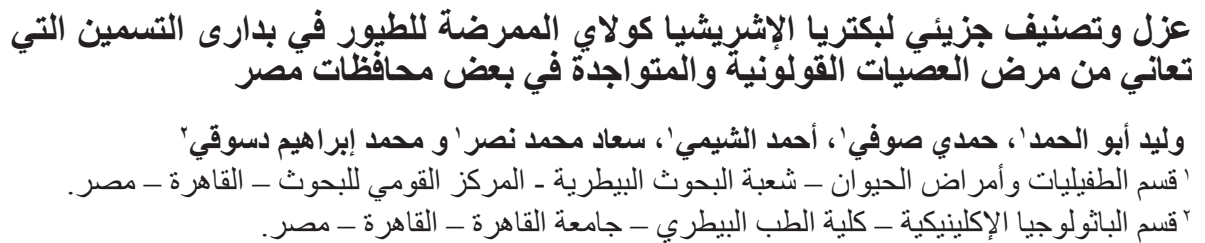

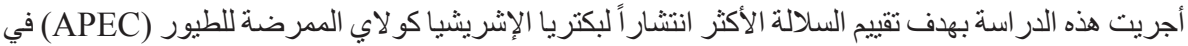

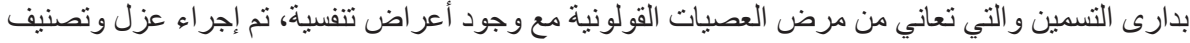

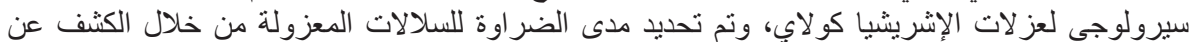

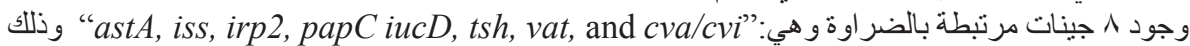

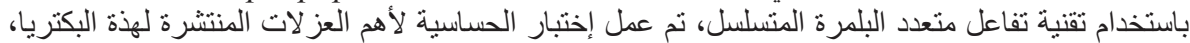

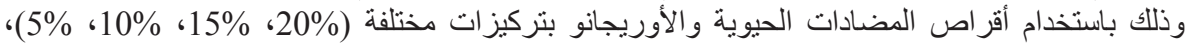

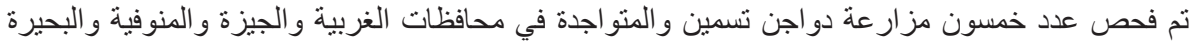

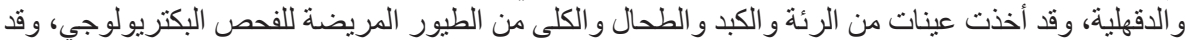

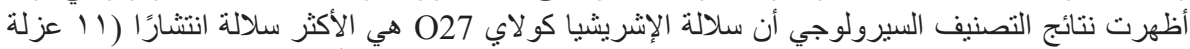

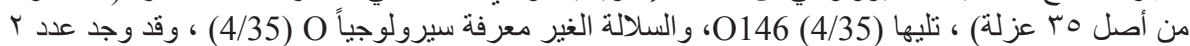

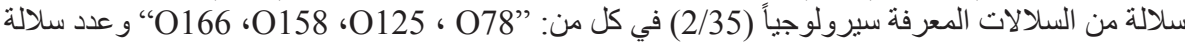

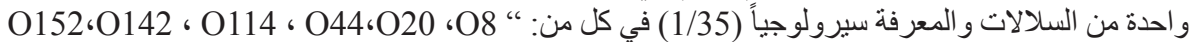

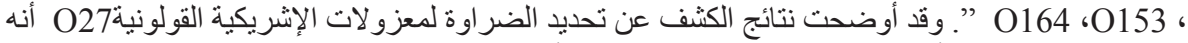

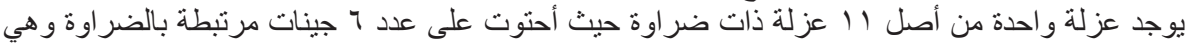

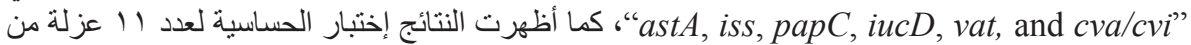

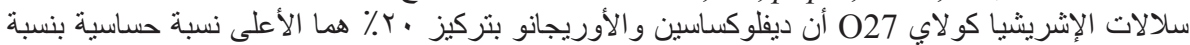

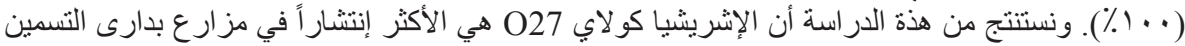

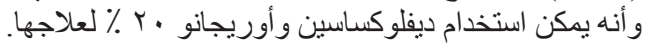

الكلمات الدالة: التصنيف السيرولوجي و الجزيئي، الإشريشيا كو لاي الممرضة للطيور O27، إختبار الحساسية، بدارى التسمين. 